\title{
Union Citizenship Revisited: Multilateral Democracy as Normative Standard for European Citizenship
}

\author{
Antoinette Scherz \\ Centre for Advanced Studies Justitia Amplificata, Goethe University Frankfurt am \\ Main, Germany \\ Rebecca Welge \\ Department of Political Sciences, University of Zurich, Switzerland \\ Antoinette Scherz \\ Goethe University Frankfurt \\ Am Wingertsberg 4, 61348 Bad Homburg v.d. Höhe, Germany \\ +496172 13977-54 \\ scherz@em.uni-frankfurt.de \\ Rebecca Welge (corresponding author) \\ University of Zurich, Department of Political Science \\ Affolternstrasse 56, CH-8050 Zurich, Switzerland \\ +41(0)446345203 \\ rebecca.welge@uzh.ch
}

\section{Acknowledgements}

This paper was written in the context of the Swiss National Center of Competence in Research Democracy. Funding by the Swiss National Science Foundation is gratefully acknowledged. For valuable comments on previous versions, we thank particularly Francis Cheneval, Dora Kostakopoulou, Kalypso Nicolaïdis, Frank Schimmelfennig, and the anonymous reviewers.

Funding Paragraph

This work was supported by the Swiss National Science Foundation under the Swiss National Center of Competence in Research Democracy. 


\title{
Union Citizenship Revisited: Multilateral Democracy as Normative Standard for European Citizenship
}

\begin{abstract}
Union Citizenship as currently implemented in the European Union introduces a distinct concept of citizenship that necessitates an adequate normative approach. The objective of this paper is to assess EU Citizenship against the theoretical background of multilateral democracy. This approach is specifically suited for this task, as it does not rely on a nation-state paradigm or the presumption of a further transformation into a federation or union. We propose three criteria by which to assess multilevel citizenship: equal individual rights, equal sovereignty of peoples, and the balancing of individuals' and peoples' interests. We argue that the current practice of Union Citizenship does not fully meet the proposed standards, regarding equal rights within, and equal access to, the political system. Based on our assessment, we propose reform options of access to national and supranational citizenship, and argue for supranational participation rights and equal transnational rights to gradually re-establish full membership for individuals.
\end{abstract}

Keywords: EU, Equality, Integration, Legitimacy, Transnational

\section{Introduction}

European Citizenship is of unique importance for migration in Europe, because it transcends national boundaries and guaranties the right to free movement to all EU citizens. Due to its multilevel structure, European Citizenship has a distinct form composed of national and EU Citizenship. It mirrors the multi-layered legal system and the complex relationship between national and EU law. According to the Treaties, every citizen of EU Member States holds EU Citizenship, which is 'additional' to national citizenship and does not replace it (Art. 20.1 TFEU). The supranationally enshrined status of EU Citizenship creates distinct features of citizenship: such a multilevel citizenship stretches into supranational and transnational realms, which are additional to the national level as it embeds multiple national communities. ${ }^{i}$ The framework of EU Citizenship has changed the conditions of migration in Europe fundamentally and could 
serve as a model how to deal with challenges of citizenship and migration in the 21 st century.

The importance of European Citizenship for the democratisation of the European Union is extensively debated (Soysal 1994; Shaw 1998; Wiener 1997; Archibugi, Held, and Köhler 1998; Kostakopoulou 2000; Bellamy and Warleigh 2001; Bauböck 2007; Bellamy 2008). Since the formal implementation of Union Citizenship in the Treaty of Maastricht, scholars have discussed the kind of construct Union Citizenship is and what it should be (Closa 1992; Meehan 1993; Kostakopoulou 1996; Preuss 1996; Lehning and Weale 1997; Shaw 1997; La Torre 1998; Eder and Giesen 2001). Adding to this debate, some scholars have argued that citizenship beyond the state lacks substance and that Union Citizenship would be merely symbolic (d'Oliviera 1995; Everson 1995; Evans 1998); others that Union Citizenship would unfold a transformative process of citizenship denationalitisation (Meehan 1993; Linklater 1998; Kostakopoulou 1996; Wiener 1998). These differences affect also the importance that is attributed to Union Citizenship with regard to internal EU migration.

Existing theoretical contributions specific to Union Citizenship differ in the extent to which Union Citizenship should remain rooted in national citizenship (Bauböck 1994; Bellamy and Castiglione 1998; Bellamy and Castiglione 1998; Weiler 1999) or represent a tableau for post-national citizenship (Kostakopoulou 1996; Kostakopoulou 2007; Linklater 1998; Wiener 1997; Garot 1998). Either way, existing theories addressing European Citizenship tend to favour unionist or pluralist perspectives. The specific characteristics of multilevel citizenship, however, require a normative approach that balances the tension between unionist and pluralist approaches. We aim at presenting such standards for multilevel citizenship based on the normative approach of multilateral democracy (Cheneval 2011; Bohman 2007; Nicolaïdis 2004; Nicolaïdis 
2013). Multilateral democracy, as democracy between democratic states, is based on the political equality of individuals and people, i.e. demoi. ${ }^{\text {ii }}$ Peoples are regarded as normatively important because they are democratic collectives of individuals and form a realm of justice (Cheneval, 2011, 117). Since the interests of individuals using their rights and the interests of the community might not be the same, tension might arise between the demands of peoples and individuals (Marshall 1950). Multilateral democracy can neither neglect nor dissolve this tension, but provides means to balance the interests of both.

We present three general criteria by which to assess the present construction of EU Citizenship. First, European Citizenship should protect individuals' rights in an equal manner. Second, the conception of citizenship should ensure peoples' right to selfdetermination. Third, the construction should balance the interests of individuals and peoples. In contrast to post-national approaches, multilateral democracy is still a bounded system that takes into account the existing state-based demoi. In comparison to cosmopolitan approaches, equality of individuals refers therefore to citizens within the bounded system. In this sense we focus on issues that are specifically important for internal EU migration.

\section{State-based and multilevel Citizenship Concepts}

State-based citizenship determines nationality and links individuals to a single political entity. Citizenship is the legal tool by which a political community defines its citizenry (Brubaker 1992). In the traditional understanding of citizenship, it is up to the political community to define their members (Magnette 2005). Due to the multilevel conception of the EU system, citizenship is composed of different political communities: it expands vertically to include a supranational level, and horizontally in that it affects multiple 
states (Shaw 1997; La Torre 1998; Bellamy and Warleigh 2001; Kostakopoulou 2000). This vertical and horizontal extension of citizenship affects the logic of citizenship at its core.

Political rights granted by citizenship shall empower individuals by entitling persons to engage or not in a course of action (Benhabib 2004; Mancini, G. Federico 1998). We restrict our analysis to political rights because political rights are foundational and underlie other citizenship rights (Janoski and Gran 2002). Entitling persons in a meaningful way, political rights granted by citizenship in liberal democracies are pivotal for the democratic quality of the system. In a democracy, citizens shall be entitled to participate on equal footing in their political community (cf. Arendt 1968; Benhabib 2004). In a multilateral democracy with multiple levels, this includes not only the domestic, but also the supranational and transnational realms, because individuals are regarded as equals throughout the whole system.

A state-based understanding of citizenship explains why the term citizenship is frequently used synonymously with nationality, which refers to individual membership to a nation-state. ${ }^{\text {iii }}$ As mentioned earlier, we understand EU Citizenship as compound: citizenship in the multilevel polity is not equivalent to nationality since individuals with different national citizenships are granted EU Citizenship as a common legal status (Closa 1992; Shaw 1997).

In traditional systems, the scope of citizenship is a comparatively straightforward concept. Whoever is a citizen (a legal member) of the political community is entitled to exercise rights and is subject to duties of citizenship. ${ }^{\text {iv }}$ The multilevel structure, however, implies that citizens are embedded in multiple citizenships: individuals are subject to national citizenship and, in the realm of EU law, to European citizenship, either as static or mobile EU citizens. 
These substantial differences necessitate a specific normative approach to evaluate citizenship. The concept of transnational or nested citizenship grasps the layers of citizenship beyond the state and theorises its specific characteristics (Bauböck 1994; Mancini, G. Federico 1998; Shaw 1998). Transnational citizenship emphasises the horizontal dimension, the multiplication of memberships and the effects of migration while nested citizenship captures the vertical construction of citizenship in multilevel systems and highlights the effects of the overlapping or 'nested' communities an individual belongs to. Based on multilateral democracy, we elaborate a new approach to multilevel citizenship that aims to integrate both of these aspects.

\section{A new normative Approach to multilevel Citizenship}

Existing normative approaches to multilevel citizenship do not give equal weight to the different aspects of EU citizenship and the fundamental relation between the national and supranational level as they tend to favour one over the other. Pluralist approaches that defend a 'thin' Union Citizenship, which complements and derives from national citizenship favour the national level (e.g., Everson 1995; Weiler 1997). Other approaches see the development of supranational citizenship as a first step towards global citizenship, overcoming the national (Lehning and Weale 1997) and, thereby, favour the supranational or post-national. By applying the framework of multilateral democracy, we aim at integrating the idea of 'Union of peoples' (Nicolaïdis 2004; 2013; Bellamy and Castiglione 1998, 267) with transformative approaches (Preuss 1996; Kostakopoulou 1996) that acknowledge the dynamic and changing nature of communities. 


\section{A Multilateral Democracy}

Multilateral democracy is a theory determining how democratic relationships between several democratic states or peoples should be organised to be legitimate (Cheneval 2011; Bohman 2007; Nicolaïdis 2004; 2013). For multilateral democracy it is fundamental that peoples and citizens are normatively equally important. The institutional implementation of this equality, however, requires further interpretation, which we search to provide for citizenship under the term of balancing.

The ideal theory of multilateral democracy is based on a membership structure of liberal democratic peoples (Cheneval 2011). Such liberal democratic peoples are defined by rule of law including individual fundamental rights, constitutional constraints of power and participatory and responsive structures, which are constitutionalised in states. In other words, only liberal democratic states are allowed to enter a multilateral democracy as Member States (Cheneval 2011). According to multilateral democracy just principles are acceptable in an original position for both liberal democratic peoples and liberal democratic citizens (Cheneval 2011). Unlike in Rawls' The Law of Peoples (1999), for multilateral democracy there are not two different original positions - one on the domestic and one on the international level. For this reason, multilateral democracy is based on the interests of both peoples and citizens. Since liberal states should not hinder their citizens from engaging transnationally. They may migrate, conduct business or engage in civil society actions in other states.

Multilateral democracy puts emphasis on the EU's multilevel character; it differs from pluralist approaches insofar as it acknowledges the existence of a broader political community, and from unionist approaches, as it does not neglect the existence of multiple demoi. The accounts of multilateral democracy all start with the presumption 
that democratic national demoi exist in the EU's multilevel system and should be taken into account. They argue that multilateral democracy is better fitted to the EU's reality and is thus a more adequate normative theory. Nevertheless, the accounts differ with regard to the question of whether multilateral democracy or demoicracy can also be transformed into a post-national system. Supporters of multilateral democracy argue either that bounded demoi are worth preserving (Cheneval and Schimmelfennig 2013; Nicolaïdis 2004; 2013) or that the transformation of demoi is legitimate if they themselves decide on it (Cheneval 2011). In our opinion, the demoi can legitimately change and transform their boundaries being fundamentally politically-constituted communities and normatively relevant insofar as they are democratic. This view is closer to approaches of post-national citizenship but acknowledges today's reality of distinct democratic peoples.

\section{B Principles for multilevel citizenship}

Multilateral democracy provides the means to establish standards of citizenship in the EU's multilevel system that are not based on the nation-state model. The existing literature on multilateral democracy does not, however, outline specific criteria for multilevel citizenship despite its being one of the most fundamental institutions of multilateral democracy. We refer to five of the principles of multilateral democracy, proposed by Cheneval as the most relevant for multilevel citizenship:

1. Sovereignty of the statespeoples' pouvoir constituant regarding entry, exit, and basic rules of the political order of multilateral democracy

2. Non-discrimination of statespeoples and citizens

3. Reciprocity of transnational rights 
4. Equal legislative rights of citizens and statespeoples

5. Supremacy of multilateral law and jurisdiction ${ }^{\mathrm{v}}$

According to Cheneval and Schimmelfennig $(2011,12)$, these principles do not 'have the status of basic principles of law,' but are 'to be specific to and necessary for the legitimate realization of demoicracy.' We aim at providing interpretation of these principles for citizenship under the core assumption of equality between liberal democratic peoples and citizens.

The sovereignty of the peoples' pouvoir constituant (P1) regards entry, exit, and basic rules of the political order of multilateral democracy. This means that peoples cannot be forced to join or stay in a multilateral democracy. Multilateral democracy, thus, allows the coexistence of different constitutional models and different models of democracy (Cheneval 2011, 135). Rights within the national system that are not specified by the common treaties might differ significantly from state to state. As long as the commonly ratified treaties do not specify a certain issue, the settings of constitutional rules remain in the peoples' competence. ${ }^{\mathrm{vi}}$

The second principle, non-discrimination of peoples and citizens $(\mathrm{P} 2)$, requires 'states or the multilateral order as such not [to] give preferences to some Member States without granting them to all' (Cheneval 2011, 140). This principle implies equal implementation of individual rights granted by the unanimously ratified treaties within each Member State without discrimination to all citizens under jurisdiction of the Member State. It does not, however, require equal rights in all Member States but the equal implementation of rights provided by Community Law.

The reciprocity of transnational rights (P3) specifies how to deal with rights (and duties) in the transnational realm. 'In such a system the fundamental liberal right to exit 
will thus be reciprocated by all member peoples by a fundamental right to entry and corresponding rights that gradually re-establish a migrant's status as full member of society' (Cheneval and Schimmelfennig 2011, 16). The claim that migrating citizens have a right to gradually re-establish full membership to a community equals neither the idea of denizenship as it is restricted to migrating EU citizens, nor simplified naturalisation rules as suggested inter alia by Bauböck (1994), but rather stems from the core idea of 'community of communities' according to which all citizens of EU Member States are potential citizens of all EU Member States.

In order to establish a comprehensive normative account of multilevel citizenship, it is important to understand how these principles relate to each other. Tensions might arise, for instance, between the sovereignty of peoples (P1) and the non-discrimination of citizens (P2) or the supremacy of common law and jurisdiction (P5). In order to develop them further regarding their meaning for citizenship, we have to consider fundamental presuppositions apparent in the original position. The three fundamental relations of equality that lie at the heart of multilateral democracy are the equality of peoples, the equality of individuals and the equality of peoples and individuals. We take these three foundations of multilateral democracy as superior guidelines for multilevel citizenship. The equality of individuals is mirrored in the supremacy of common law and jurisdiction (P5) and the non-discrimination of citizens (P2). This means supranational and transnational rights recognised in common law, are granted equally to all persons without distinction of any kind, such as sex, religion or nationality. Second, the equality of peoples translates into the sovereignty of the peoples' pouvoir constituant $(\mathrm{P} 1)$ and the non-discrimination of peoples, meaning that peoples will not give preferences to one other member-people over the others (P2). It should be noted that the criterion of equality of peoples means not only sovereignty, but also non-discrimination for peoples. 
Third, the equality of peoples and individuals translates into equal legislative rights of citizens and peoples (P4) and to the reciprocity of transnational rights (P3).

\section{Rights of Citizenship in the multilevel System}

Individual rights within the political systems can be distinguished as 'transnational rights' for citizens with different nationalities who migrate in the system and 'supranational rights' directly linked to the supranational level. Table 1 presents how the principles can be allocated to the three fundamental equality relations and specifies the implications they have for the supranational, transnational and domestic realm.

[Table 1 here]

The multilateral approach seeks to balance individuals' and peoples' interests in the supranational, transnational and national realm. On the supranational level it gives prevalence to individual equality. This means that if a right relates directly to the European level, e.g. EP voting rights, this right should be equally implemented across the Member States (see also Cheneval 2007). The balancing problem is most pressing with regard to the transnational realm. Transnational rights, per definition, can only be activated via the right of free movement and should be granted in line with mutual recognition (cf. Cheneval 2011). A reciprocal establishment of transnational rights is required for the development of further rights beyond the Treaties, opening up the possibility for differentiated integration. However, if the provision of transnational rights has been agreed upon in common law, the equality of individuals is the relevant criterion as the sovereignty of peoples has already been satisfied in the ratification. Finally, within the member states, the conflict of peoples and individuals should be resolved since multilateral democracy consists only of democratic states. In liberal democratic states, the sovereignty of the people is based on the individual, which means 
that there should not be an internal conflict if these requirements are fulfilled. In order to secure the equality of individuals also within the Member States, a minimum standard of political rights is demanded in practice.

\section{Access to Citizenship in the multilevel System}

Access and rights are much more complex in multilevel citizenship than in state-based citizenship. Access to citizenship can be defined on different levels of the system and different sets of rights and duties might be granted to different groups of individuals. This section presents normative expectations of multilateral democracy for access and linkage of citizenship and compares it to alternative approaches. ${ }^{\text {vii }}$

First, in a multilevel system, access to each level can be disconnected or connected in different ways (La Torre 1998; Eder and Giesen 2001; Kostakopoulou 2000; Bauböck 2007). If access to different levels is linked, it can generally be granted either top down or bottom up. Strongly linked bottom up access implies that citizens who are members of the lower level are automatically granted access to the higher level. Top down access implies that the citizenry of the highest level is automatically part of the lower level. The historical development of federal states shows linkages in both directions: from regional to national citizenship or vice versa. Either way, the traditional understanding of national states requires strong linkage to guarantee the unity of the demos. The linkage between different levels of citizenship has important implications for who controls access and who determines the rights and duties attached to a legal status.

Unlike in traditional federal states, citizenship in multilateral democracy does not necessarily need to be linked across the different levels. If national and supranational citizenship are linked, access has to occur through a bottom-up approach because otherwise national sovereignty would be strongly violated (Weiler 1997; Bellamy and 
Castiglione 1998). An alternative option to a bottom-up link would be to grant supranational citizenship disconnected from national citizenship, in which case the legally defined supranational demos would not necessarily be congruent with the

national demoi. ${ }^{\text {viii }}$ Access to supranational citizenship could, instead, be conditional on residency (Rubio-Marin 1998; Garot 1998; Perchinig 2006; Kostakopoulou 2007; Schrauwen 2013). Access to national citizenship should, however, remain in the legal competence of the respective political communities, which can define access conditions for their national citizenship to ensure the sovereignty of peoples in the core issue of defining the respective citizenry. This principle would not be violated if all Member States would agree unanimously to common standards of access.

[Table 2 here]

We list the normative expectations for both citizen access and linkage in Table 2 and compare it with the demands of alternative approaches. The main difference to other theoretical perspectives lies in the differentiated access to multilevel citizenship. While statist approaches favour the self-determination of access to the whole system, unionist perspectives favour uniform access for all. Linkage in all these approaches is strictly linked and only disconnected for TCNs.

\section{Realisation of multilateral Principles in European Citizenship}

This section aims to (a) evaluate the current construction of EU Citizenship as institutionalised in law and (b) present reform options that could increase the legitimacy of multilevel citizenship in light of multilateral democracy. 


\section{A Access to Citizenship Status}

Generally, equality of peoples suggests that regulations of acquisition and loss of national citizenship shall remain in the competence of Member States. Access to the supranational level, however, does not necessarily have to be linked to access to national citizenship. Therefore, access to citizenship can, from the perspective of multilateral democracy, be legitimately constructed in two ways: through bottom-up linkage or separate national and supranational access. We discuss in which way these options could increase the legitimacy of multilevel citizenship in the European Union compared to the Status Quo.

Currently, access to EU Citizenship is strongly linked to national citizenship. According to the Treaties, every National of a Member State shall be an EU citizen. EU Citizenship is 'additional' to national membership and does not replace it. When implemented in 1992, EU Citizenship was meant to be 'complementary' to national citizenship. The status of EU Citizenship has always been linked bottom-up in its access and loss. This strong linkage means that one cannot hold EU Citizenship without being a Member State national. ${ }^{\text {ix }}$

At first glance, the bottom-up linkage between national citizenship and EU Citizenship seems to realise the sovereignty of the pouvoir constituant of the Member States, as each Member State retains the sovereignty to decide who their citizens are by formulating access conditions. Naturalisation procedures, however, vary widely among Member States while the result remains the same: each national for the purpose of community law is automatically an EU citizen and can benefit from transnational and supranational rights in the whole system. In this construction of access, the Member States keep the sovereignty to define their own citizens, however, they do not control who can become citizens of the multilevel system since they do not have a say in the 
naturalisation rules of other Member States. From the perspective of multilateral democracy, this lack of the competence to decide who shall be EU citizens is of high relevance in the context of migration. Thus, the lack of common standards becomes a crucial issue as it eludes control over access to the political system.

EU Citizenship includes not only the supranational, but also the transnational rights of the multilevel system. In consequence, EU citizens also benefit from rights related to the national or local level of other Member States. Further, multilateral democracy claims that EU citizens shall not only have a right to free movement and residence, but also to 'gradually become full members' if they decide to engage transnationally (Cheneval and Schimmelfennig 2011, 16). ${ }^{\mathrm{x}}$ The claim of granting migrating EU citizens access to the political systems, which distinguishes multilateral democracy from pluralist approaches, implies that states accept EU citizens as having rights equal to those of Nationals in the state of permanent residence. Given the sovereignty principle, it is problematic if states do not have a say in who these citizens are. Therefore bottomup linkage, as implemented in the status quo, poses severe problems of unequal access to supranational and transnational citizenship and loss of access-control by Member States over these two levels.

From the perspective of multilateral democracy, peoples should retain full competence in defining their national naturalisation rules while citizenship on the supranational level should be equally accessible for all individuals. For this reason, the status quo is more problematic than alternative designs: a lack of common naturalisation standards at the national level combined with automatic access to supranational citizenship for national citizens makes control over access to supranational citizenship impossible. Since supranational citizens should be granted a right to gradually re-establish full membership in each political community, access to national citizenship is eluded if 
access to supranational citizenship is not controlled by all peoples. Three models of access to supranational citizenship, as illustrated in Table 3, are in principle possible for multilateral democracy. These models include first, a bottom-up linkage model (status quo); second, a decoupled model in which access to the national level is decoupled from access to the supranational level (with or without an institutional opening for TCNs); third, a mixed model (with or without common standards at the national level). We discuss these models with regard to the equality of individuals and inclusiveness, on the one hand, and the sovereignty of peoples, on the other hand.

[Table 3 here]

A bottom-up 'linked' model (1), assumes an automatic link, which guarantees that all members of the national demoi are also members of the supranational one as realised in the status quo (option 1a). The status quo realises an automatically linked citizenship without common standards. To improve the status quo but remain in the model of bottom-up linkage would require minimal common standards for naturalisation at the national level to which all states would have to agree (1b). This implies that the peoples would gain the competence to define who can become a supranational citizen. It might be argued against minimal common standards that, in a multilateral democracy, all Member States are democratic and, as such, mutually recognised by each other. However, rules for naturalisation might be changed in a national state, and this could be problematic for multilateral democracy in several ways: underinclusiveness of naturalisation rules, on the one hand, might lead to a lack of democratic legitimacy in a Member State and consequently affect democratic quality of the whole system. Overinclusiveness of naturalisation rules, on the other hand, could lead to distinct problems in the national, transnational, and supranational realm. This can for example be caused by extraterritorial mass naturalisations as offered by several member states on 
grounds of ancestry or co-ethnicity. On the domestic level, this results in the possibility of dominance of external votes. In the transnational realm, it could lead to the subversion of other Member States' rights to control immigration. At the supranational level, overinclusive naturalisation rules could be misused to influence the representations in supranational institutions disproportionally through artificially higher numbers of citizens. Minimal common standards can be a mean to impede the problematic effects of over- and underinclusive naturalisation rules on the multilateral polity.

An automatically linked approach favours one level over the other. The two alternative approaches, decoupled and mixed, can realise the equal importance of both statuses, which is favourable according to theoretical approach of multilateral democracy. If the national and the supranational levels of citizenship were disconnected, the competence to define conditions of access to the national level would remain at the national level, while Member States would have to agree on common standards of access to the supranational and the transnational realms. Multilateral democracy would favour the decoupled options over an automatically linked option, because it leaves control over national access to the respective states and at the same time guarantees their control over the supranational level through common standards. This means that the decoupled options can solve the main problem of sovereignty loss over multilevel citizenship for peoples.

Option $2 a$ defines national citizenship as a necessary but insufficient condition for supranational citizenship. As a result, some national citizens would not hold supranational citizenship, but all supranational citizens would hold national citizenship. ${ }^{\mathrm{xi}}$ Even though such exclusion does not comply with the equality between citizens in a multilevel polity, it can be justified if the sovereignty of peoples is 
undermined by the naturalisation procedures of other states. This is specifically the case if these procedures fall outside of the usual democratic requirements, such as extraterritorial mass naturalisations, and are therefore not covered by mutual recognition. Of course, it depends on the implemented common standards, which nationals exactly would not acquire EU citizenship under this model. Option $2 b$ sets the common standards for supranational citizenship in such a way that it provides access to supranational citizenship for individuals who are not national citizens, as discussed in the idea of 'civic citizenship.' In $2 \mathrm{a}$ and $2 \mathrm{~b}$, some of the Nationals might not be included in supranational citizenship, but $2 \mathrm{~b}$ is more inclusive as it provides an institutional opening for TCNs. For this reason, multilateral democracy would favour $2 \mathrm{~b}$ over $2 \mathrm{a}$.

The mixed models are defined through a link from the national to the supranational level and an access option for TCNs to supranational citizenship. ${ }^{\text {xii }}$ TCNs could acquire supranational citizenship without holding or gaining nationality. For instance, it could be acquired after a certain period of residence within the territory of the multilateral democracy (Garot 1998; Kostakopoulou 2000). Compared to the status quo, option $3 a$ would provide an institutional opening for TCNs to supranational citizenship. ${ }^{\text {xiii }}$ It would also ensure all national citizens automatic supranational citizenship through an automatic linkage. Since national citizenship is not bound to common standards in option 3a, automatic access for all Member State Nationals could still bypass the common standards for supranational citizenship. Therefore, such a design does not solve the problem of control for peoples over access to the supranational level for other national citizens. In option $3 b$, control over access to supranational citizenship would not be bypassed: in contrast to the decoupled option, Member State Nationals would still be automatically granted supranational citizenship and TCNs could access supranational citizenship, but the inclusion of all citizens would be regulated through 
minimal common standards on the national level. Hence, it would resolve the sovereignty problem for peoples over access to supranational citizenship. This requires, to a certain extent, the harmonisation of naturalisation rules at the national level, which affect in turn national sovereignty. If harmonisation takes the form of minimal standards for access to national citizenship, it would not be particularly invasive.

Another argument can, however, be made against the decoupled and the mixed model from a demoicratic point of view. Decoupling Union Citizenship constructs a separate European demos. This construction of a European demos is understood to contradict the fundamental idea of multilateral democracy as a demoicracy only if it would result in the domination of certain national demoi or even to their replacement. An emerging European demos, however, would still embed the national demoi and European citizenship would not replace the national ones. Finally, common standards for such a procedure would not undermine the ideal of multilateral democracy since they are inherent part of mutual recognition, which is a fundamental principle of multilateral democracy (Nicolaïdis 2013, 359-60).

To summarise, a decoupled model that provides an institutional opening for TCNs $2 b$ or a mixed model that applies minimal common standards at the national level $3 \mathrm{~b}$ would be the best options to realise the ideal of multilateral democracy. This argument flows from the core claim that each migrating citizen in a multilateral democracy has the right to gradually re-establish full access to the political system. In combination with linked citizenship (without common standards) this challenges peoples' sovereignty to decide who becomes a member of the community. Both reform options can improve the status quo and balance the interests of individuals and peoples in the multilevel system. The desirability of model $2 \mathrm{~b}$ depends on the inclusion of nationals while granting common standards. Just like option $3 \mathrm{~b}$, option $2 \mathrm{~b}$ implements minimal standards for 
supranational citizenship and realises an institutional opening for TCNs, but increases the sovereignty of peoples as they retain the right to define naturalisation rules for national citizenship.

\section{B Citizenship Rights}

In addition to rights in the national sphere, effective EU citizenship needs to create links between individuals and the supranational and the transnational spheres of the EU's political system. We will now briefly discuss the current framework of rights in light of multilateral democracy separately for three realms: rights related to the supranational level, rights related to the transnational realm, and rights within the state of nationality. ${ }^{\text {xiv }}$

\section{$i \quad$ Rights related to the supranational Realm}

Following the principles of multilateral democracy, rights that relate to the supranational realm shall realise, in accordance with the double equality relationship, the implications derived in Section II, namely:

a. Equal implementation of supranational rights in the whole system (individuals)

b. Residence-independent application (individuals)

c. Legal security for the application of common rules (peoples)

d. Veto in the adoption of common rules for access and loss of supranational citizenship (peoples)

e. Participation rights for individuals to establish legislative representation (balancing)

f. Veto of peoples in the adoption of common rules (balancing) 
The equality of individuals is insufficiently realised if implementation measurements differ, even for rights that are strictly related to the supranational level and do not influence national matters. ${ }^{\mathrm{xv}}$ Accordingly, voting rights for the EP elections and accountability rights towards the EU institutions (such as the right to petition the EP) should be identical for all EU citizens. This could be met if national lists and candidates for EP elections were abandoned in favour of exclusively European-wide lists. Alternatively, the requirement of identical voting rights could also be met by applying either strict residence based or nationality based voting rules for all EU citizens residing in another Member State.

Some rights presuppose the exercise of free movement. In consequence, EU citizens who spend their lives in their country of nationality are excluded from some rights that are granted to those who exercise their right to free movement. The principle of equality, however, requires establishing these rights as minimal rights for all citizens, though each Member State could go beyond these provisions. The equal implementation of supranational rights and the further creation of effective participation rights for individuals to establish legal representation at the supranational level are required as the two most important steps for multilateral democracy in order to further develop supranational rights in the EU.

\section{ii Rights related to the transnational Realm}

As argued in Section II and illustrated in Table 1, the following implications are derived from the principles of multilateral democracy:

a. Entry rights and political rights, gradually re-establish full membership (individuals)

b. Non-discrimination for rights settled in Treaties (individuals) 
c. Competence to regulate acquisition and loss of national citizenship (peoples)

d. Veto in the adoption of common rules (peoples)

e. Non-discrimination for rights settled in Treaties (peoples)

f. Differentiated integration possible (balancing)

The first transnational right granted to individuals in the EU was the free-movement right for workers in the 1950s. The right to entry, in this respect, was at the core of citizenship practices in the EU from the beginning of EU integration and heavily influenced the development of EU Citizenship.

Besides the right to free movement itself, the transnational sphere of EU Citizenship includes citizenship rights such as the right to work, study and reside in the host state. In fact, most EU Citizenship rights are activated when an EU citizen resides in another Member State. As a result, the realisation of transnational rights can create situations that strongly violate the assumption of equality between individuals and the related principle of non-discrimination. According to the standards of multilateral democracy, each right that is granted to EU citizens in the transnational realm needs to be granted to the Nationals within the country. This means that citizens living in another Member State could have fewer rights than Nationals but should not have more, in order to prevent reverse discrimination (as it is currently the case for the right to Family Reunification granted by EU Law). As Member States commonly agreed to the introduction of a transnational right, it is not a violation of Member State sovereignty to demand that those rights are extended to all Member State citizens.

The gradual re-establishment of full membership for EU citizens living in a host Member State means that all kinds of citizenship rights, i.e. liberty rights, social rights and political rights, should be extended as far as possible while balancing them with the peoples' sovereignty. Regarding political rights, this is surely possible for transparency 
and accountability rights. Participation rights should also be made accessible in accordance with the duration of residence. This does not mean, however, that transnational rights lead ultimately to naturalisation and therefore to national citizenship.

The claim to gradually re-establish full membership in a state implies that individuals shall have the right to participate in all elections after a sufficient period of time. At the local level, and even more so at the national level, the issue of double- and underrepresentation has to be considered. In practice, EU citizens can double vote in EP elections since, up to now, the EU is lacking a common voter register. Conversely, EU citizens might lose their right to participate in national elections as their state of nationality requires residence and their host state requires nationality. Currently, however, only few states require residency for voting rights in national elections (Arrighi et al. 2013; Bauböck et al. 2012). From the perspective of multilateral democracy, it is not acceptable that individuals in the system might have no participation rights at the national level in any Member State.

In contrast to the reciprocity standards of multilateral democracy, some Member States grant certain rights to Non-Nationals because of former links between these countries, but do not extend these rights to other EU Nationals. ${ }^{\text {xvi }}$ According to the standards of multilateral democracy, transnational rights must not give preference to some Member States over others. Yet, deeper integration outside of common law, based on autonomously taken measures at the national level or as the result of a collective initiative, could eventually attract all other Member States into this agreement (Shaw $2007,2557)$. In this sense, deeper integration on a reciprocal basis is always desirable if it leads to an extension of individual rights in the multilevel system. 


\section{iii Within Community}

Rights within the Member States' communities shall be realised in accordance with the sovereignty of the peoples' pouvoir constituant. Thus, the non-domination of citizens shall be realised within the Member States without regulation from the supranational level. As argued in Section 2.3, two exceptions exist in which the common legal system needs competences to constrain Member State sovereignty:

a. Minimum standards of political rights (individuals)

b. Coexistence of different citizenship models (peoples)

The question of common standards of democratic rights within the Member States relates to the issue of EU competences and the scope of EU law, as well as its limits. Generally, common law and EU citizenship rights are not applicable to purely internal situations. However, the distinction between what is internal and what is within the scope of EU law is not always clear-cut. In line with theoretical expectation, individual rights granted by the Member States are in the competence of national institutions. Consequently and legitimately, Nationals of different Member States may have different rights and duties resulting from differences between the national legal systems and the respective national citizenship provisions. Commonly established rights should function as the minimal criteria of individual rights within the Member States.

\section{Conclusion}

Union Citizenship is a unique legal framework to deal with intra-EU migration and its effects on political participation. As we argued in this paper, the specific characteristics of multilevel citizenship require appropriate normative standards and cannot be evaluated on the basis of a nation-state paradigm or post-national conceptions. The aim of this paper was to assess European Citizenship according to multilateral democracy as 
a specific standard dedicated to democratic relations between several democratic states. Multilateral democracy is a normative ideal specific to such multilevel systems based on several democratic peoples that is well suited for this task.

In contrast to a purely unionist or pluralist view, the account of multilateral democracy does not privilege individuals or peoples. It seeks to balance the sovereignty of peoples and the non-discrimination of citizens throughout the system. Our approach follows Weiler (1997) and Bellamy and Castiglione (1998) insofar as we argue that a European community can co-exist with national communities without replacing them. But, in contrast to existing approaches, we seek to give prevalence neither to national citizenship nor to supranational citizenship, but rather argue for the equal standing of both. The approach we present here seeks not to overcome 'tensions generated by these opposing elements' (Kostakopoulou 2000, 486), but to balance them. This results in a more inclusive approach of a multilevel system that takes peoples as well as static and migrating individuals into account. Our paper therefore promotes an ideal of citizenship for the EU that is not committed to a vision of the EU other than that of democratic relations between peoples.

In light of multilateral democracy, the current implementation of European Citizenship is problematic, specifically as regards equal rights within, and equal access to, the political system. Regarding the reforms of rights, citizenship in a multilateral democracy needs to realise equal implementation of supranational rights in the whole system and residence-independent application of these rights to guarantee the equality of individuals, which is specifically important for migrating individuals. Balancing the interests of peoples and individuals in the supranational realm requires further participation rights for individuals to establish legislative representation in addition to the representation of collective interests. ${ }^{\text {xvii }}$ Regarding the transnational realm, the 
equality of individuals can be realised through entry and political rights to gradually reestablish full membership and to facilitate migration. Regarding citizenship rights within the national level, the system needs minimum standards of political rights that respect the sovereignty of peoples and the coexistence of different citizenship models.

EU Citizenship grants individuals enforceable rights; nevertheless, large inequalities can remain for individuals as long as acquisition and loss of EU Citizenship depend on national citizenship. An automatically linked model of EU Citizenship access is simultaneously problematic for the sovereignty of peoples. They remain powerless regarding how other nation states grant nationality and, consequently, lack control over access to EU Citizenship. The core argument we develop is thus that the theoretical framework of multilateral democracy favours either a decoupled model with Union Citizenship as an independent status with an institutional opening for TCNs or a mixed model with minimal common standards for national citizenship. In contrast to the mainstream argument that a disconnected EU Citizenship results in a loss of sovereignty, we argue that it can even improve the equal freedom of individuals and peoples. Further it copes better with challenges of intra-EU migration because it allows EU citizens to gradually re-establish full membership and acknowledges citizenship acquisition of non-EU citizens living and migrating within Europe. Therefore, detaching EU Citizenship from national citizenship can increase national sovereignty while consolidating EU Citizenship as a fundamental status for static and migrating citizens in multilateral democracy

\footnotetext{
${ }^{i}$ We distinguish between 'transnational' and 'supranational' realm. We use the term transnational in the context of internal migration i.e. EU citizens residing in Member States other than their nationality. Supranational, in contrast, refers directly to the EU level and its institutions.
} 
ii We refer to the demos in the sense of a political people, and not on a national or ethnical understanding (see e.g., Scherz 2013). In consequence, the terms 'demos', 'people', and 'statespeople' are used interchangeably in this article.

iii A discussion of differences in the use of the terms 'citizenship' and 'nationality' in political debates and legal documents in EU Member States can be found at the EUDO Citizenship webpage (see http://eudo-citizenship.eu/databases/citizenship-glossary, last accessed on 11 Sept 2013).

${ }^{\text {iv }}$ Different conceptualisations of citizenship accept the notion of individual rights and obligations towards the political community as inherent parts of citizenship. Variation exists, however, in approaches to dealing with conflicts between the norms as discussed e.g. in (van Deth 2007).

${ }^{v}$ Cheneval $(2011,132)$ suggests two additional principles that are of minor relevance for the focus of this paper: ' 6 . Two principles of linguistic justice' and '7. Difference-principle for member statespeoples'.

${ }^{v i}$ This is an issue of scope insofar as every delegation of competences to the supranational level involves interpretation with regard to the extent of harmonisation it requires.

${ }^{\text {vii }}$ This paper focuses exclusively on acquisition of citizenship, because a debate on loss cannot be held without discussing citizenship requirements outside of the multilateral polity.

viii From the perspective of multilateral democracy, participation rights should be as inclusive as possible and extended to TCNs in accordance with residence criteria (for argument for a general requirement of democracies to be inclusive see for example Dahl 1989; Gould 2007; Abizadeh 2008).

ix Accepting that EU citizenship could be disconnected from national citizenship or provide an additional institutional opening for TCNs requires acknowledging that citizenship can be detached from nationality, as suggested, e.g., by (Kostakopoulou 2000). For a critical view on this see, e.g. (Weiler 1999).

${ }^{x}$ This argument and the argument of gradually re-establishing migrants' status as full members are not made explicitly in a later version of this article, (Cheneval and Schimmelfennig 2013)

${ }^{x i}$ In fact, this option is entailed in the status quo because European Citizenship is generally granted automatically to Member State Nationals, but it is up to the Member States first to define who their Nationals 'for the purpose of community law' are.

xii Generally, the discussion of rights in this paper deals mainly with the rights of EU citizens. However, the legal framework for individual rights in the EU also includes TCNs. The status of TCNs in the EU entails not only basic freedoms and fundamental rights, but also two important principles of EU law, namely non-discrimination and equality before the law.

xiii The Concept of 'Civic Citizenship' was first introduced in 2000 in a Communication of the Commission: 'The legal status granted to Third Country Nationals would be based on the principle of providing sets of rights and responsibilities and a basis of equality with those of Nationals but differentiated according to the length of stay while providing for progression to permanent status. In the longer term this could extend to offering a form of civic citizenship, based on the EC Treaty and inspired by the Charter of Fundamental Rights, consisting of a set of rights and duties offered to Third Country Nationals' (COM(2000)757 final: 21 in (Perchinig 2006). This idea was also discussed earlier in different contributions to (La Torre 1998) and more recently by (Schrauwen 2013).

${ }^{\text {xiv }}$ The principles we use are solely rights-orientated and therefore cannot resolve all tensions related to multilevel citizenship. Generally, individuals' rights in a political community should be balanced in respect to their duties.

${ }^{\mathrm{xv}}$ Regarding the claim that individuals require direct participation rights at the supranational level to establish a legal representation of individuals able to balance the representation of peoples, EU citizens do have the right to vote (or stand as a candidate) for EP elections, either in their state of nationality or in their state of residence. Likewise, citizens have the right to initiate a citizens' initiative since the Treaty of Lisbon. Both can be seen as legislative representation of EU citizens. However, the procedure in EP elections differs across countries and candidates are elected via national election lists. Directive (93/109/EC) specifies the right to vote in EP 
elections and needs to be implemented in national law. Member States have leeway in deciding whether to add residence requirements for their own citizens or include residing EU citizens within the entitled persons. The co-existence of different combinations of citizenship or residence requirements for eligibility to participate in the citizens' initiative is problematic insofar as EU rights, granted by EU law, should realise individuals' equality.

${ }^{x v i}$ Voting rights in the UK, for example, are extended to citizens from states that belong to the commonwealth, such as Malta.

xvii The implementation of P4 "Equal legislative rights of citizens and statespeoples" does, however, not as such require strict equality of both chambers in a bicameral system but rather balanced procedures. 


\section{References}

Abizadeh, Arash. 2008. "Democratic Theory and Border Coercion: No Right to Unilaterally Control Your Own Borders.” Political Theory 36 (1): 37-65. doi:10.1177/0090591707310090.

Archibugi, Daniele, David Held, and Martin Köhler, eds. 1998. Re-imagining Political Community: Studies in Cosmopolitan Democracy. Cambridge: Polity Press.

Arendt, Hannah. 1968. The Origins of Totalitarianism. New York: Harcourt, Brace and Jovanovich.

Arrighi, Jean-Thomas, Rainer Bauböck, Michael Collyer, Derek Hutecheson, Madalina Moraru, Lamin Khadar, and Jo Shaw. 2013. Franchise and Electoral Participation of Third Country Citizens Residing in the European Union and of European Union Citizens Residing in Third Countries. Brussels: European Parliament.

Bauböck, Rainer. 1994. Transnational Citizenship: Membership and Rights in International Migration. Aldershot: Edward Elgar.

2007. "Political Boundaries in a Multilevel Democracy." In Identities, Affiliations, and Allegiances, edited by Seyla Benhabib, Ian Shapiro, and Danilo Petranović, 85-109. Cambridge: Cambridge University Press.

Bauböck, Rainer, Philippe Cayla, and Catriona Seth. 2012. "Should EU Citizens Living in other Member States Vote there in National Elections?" (No. 32).

Bellamy, Richard, and Dario Castiglione. 1998. "The Normative Challenge of a European Polity: Cosmopolitan and Communitarian Models Compared, Criticised and Combined." In Democracy and the European Union, edited by Andreas Føllesdal and Peter Koslowski, 254-84. Studies in Economic Ethics and Philosophy. Berlin Heidelberg: Springer.

Bellamy, Richard, and Alex Warleigh. 2001. Citizenship and Governance in the European Union. London: Continuum.

Bellamy, Richard. 2008. "Evaluating Union Citizenship: Belonging, Rights and Participation within the EU.” Citizenship Studies 12 (6): 597-611.

Benhabib, Seyla. 2004. The Rights of Others Aliens, Residents and Citizens. Cambridge: Cambridge University Press.

Bohman, James. 2007. Democracy across Borders: From Dêmos to Dêmoi. Cambridge, Mass., London: MIT Press.

Brubaker, Rogers. 1992. Citizenship and Nationhood in France and Germany 21. Cambridge: Cambridge University Press. http://journals.cambridge.org/production/action/cjoGetFulltext?fulltextid=6239700.

Cheneval, Francis. 2007. “'Caminante, No Hay Camino, Se Hace Camino Al Andar’: EU Citizenship, Direct Democracy and Treaty Ratification.” European Law Journal 13 (5): 647-63.

Cheneval, Francis, and Frank Schimmelfennig. 2011. "The Case for Demoicracy in the EU." EUSA Conferece Boston. http://euce.org/eusa/2011/papers/8h_cheneval.pdf.

Cheneval, Francis. 2011. The Government of the Peoples: On The Idea and Principles of Multilateral Democracy. New York: Palgrave Macmillan.

Cheneval, Francis, and Frank Schimmelfennig. 2013. "The Case for Demoicracy in the European Union." Journal of European Public Policy 51 (2): 334-50. doi:10.1111/j.1468-5965.2012.02262.x. 
Closa, Carlos. 1992. "The Concept of Union Citizenship in the Treaty on European Union." Common Market Law Review 9: 1137-69. http://www.getcited.org/pub/103388498.

d'Oliviera, J. 1995. “Union Citizenship: Pie in the Sky?” In A Citizens' Europe: In Search of a New Order, edited by Allan Rosas and Esko Antola. London, Thousand Oaks, Calif: Sage.

Dahl, Robert A. 1989. Democracy and Its Critics. New Haven, Conn: Yale University Press.

Eder, Klaus, and Berhard Giesen. 2001. European Citizenship: National Legacies and Transnational Projects. Oxford: Oxford University Press.

Evans, Andrew. 1998. "Union Citizenship and the Constitutionalization of Equality in EU Law." In La Torre, European Citizenship: An Institutional Challenge, 267-91.

Everson, M. 1995. “The Legacy of the Market Citizen.” In New Legal Dynamics of European Union, edited by Jo Shaw and G. Moor, 73-89. Oxford: Oxford University Press.

Garot, Marie-José. 1998. “A New Basis For European Citizenship: Residence.” In La Torre, European Citizenship: An Institutional Challenge, 229-50.

Gould, Carol C. 2007. “Transnational Solidarities.” Journal of Social Philosophy 38 (1): 148-64.

Janoski, T., and B. Gran. 2002. "Political Citizenship: Foundation of Rights." In Handbook of Citizenship Studies, edited by Engin F. Isin and Bryan S. Turner, 13-52. London: Sage.

Kostakopoulou, Dora. 1996. "Towards a Theory of Constructive Citizenship in Europe.” Journal of Political Philosophy 4 (4): 337-58. http://onlinelibrary.wiley.com/doi/10.1111/j.14679760.1996.tb00056.x/full.

2000. "The European Citizenship Menu: Modes and Options. [Review essay]." Journal of European Public Policy 7 (3): 477-92. http://eprints.soton.ac.uk/202719/.

_. 2007. "European Union Citizenship: Writing the Future.” European Law Journal 13 (5): 623-46. http://onlinelibrary.wiley.com/doi/10.1111/j.1468-0386.2007.00387.x/full.

La Torre, Massimo, ed. 1998. European Citizenship: An Institutional Challenge. The Hague: Kluwer Law International.

Lehning, Percy B., and Albert Weale, eds. 1997. Citizenship, Democracy, and Justice in the New Europe. London: Routledge.

Linklater, Andrew. 1998. "Cosmopolitan Citizenship.” Citizenship Studies 2 (1): 23-41.

Magnette, Paul. 2005. Citizenship: The History of an Idea: ECPR Monographs. Edited by Alan Ware. Colchester: ECPR Press.

Mancini, G. Federico. 1998. "Europe: The Case for Statehood.” European Law Journal 4 (1): $29-42$. http://www.euraction.org/committee/newsletter/mancini.pdf.

Marshall, Thomas H. 1950. Citizenship and social class and other essays: Cambridge.

Meehan, Elizabeth M. 1993. European Citizenship. London: Sage.

Nicolaïdis, Kalypso. 2004. “The New Constitution as European 'Demoi-cracy’?” Critical Revs. of Int. Social \& Political Philosophy 7 (1): 76-93. . 2013. "European Demoicracy and Its Crisis.” JCMS 51 (2): 351-69. doi:10.1111/jcms.12006.

Perchinig, Bernhard. 2006. "EU Citizenship and the Status of Third Country Nationals." In Migration and Citizenship: Legal Status, Rights and Political Participation, edited by Rainer Bauböck, 67-82. Amsterdam: Amsterdam University Press. 
Preuss, Ulrich K. 1996. “Two Challenges to European Citizenship.” Political Studies 44 (3): 534-52. http://onlinelibrary.wiley.com/doi/10.1111/j.1467-9248.1996.tb00599.x/full.

Rawls, John. 1999. The Law of Peoples. Cambridge, Mass: Harvard University Press.

Rubio-Marin, Ruth. 1998. "Equal Citizenship and the Difference that Residence Makes.” In La Torre, European Citizenship: An Institutional Challenge.

Scherz, Antoinette. 2013. "The Legitimacy of the Demos: Who Should Be Included in the Demos and on What Grounds?" Living Reviews in Democracy 4 (0).

http://democracy.livingreviews.org/index.php//rd/article/view/25.

Schrauwen, Anette. 2013. "Granting the Right to Vote for the European Parliament to Resident ThirdCountry Nationals: Civic Citizenship Revisited.” European Law Journal 19 (2): 201-18.

Shaw, Jo. 1997. “The Many Pasts and Futures of Citizenship in the European Union.” European Law Review 22 (1): 554-72.

1998. "Citizenship of the Union: Towards Post-National Membership?" In Collected Courses of the Academy of European Law, edited by Academy of European Law, 237-347. The Hague: Kluwer Law International. http://cadmus.eui.eu/handle/1814/3014.

2007. "E.U. Citizenship and Political Rights in an Evolving European Union.” Fordham Law Review (75): 2549-79.

Soysal, Yasemin N. 1994. Limits of Citizenship: Migrants and Postnational Membership in Europe. Chicago, Ill: University of Chicago Press.

$\mathrm{http} / / /$ books.google.ch/books?hl=en\&lr=\&id=jJP611wZmQkC\&oi=fnd\&pg=PP8\&dq=Soysal+1994\&o $\mathrm{ts}=\mathrm{vdPLcOD} 3 \mathrm{vz} \& \mathrm{sig}=$ S1JCDUJwdr6cvFnvk7 jkBynB-o.

van Deth, Jan. 2007. "Norms of Citizenship." In Political Behavior, edited by Russel J. Dalton and HansDieter Klingemann. Oxford: Oxford University Press.

Weiler, Joseph H. H. 1997. “To be a European Citizen - Eros and Civilization.” Journal of European Public Policy 4 (4): 495-519.

1999. The Constitution of Europe: 'Do the New Clothes Have an Emperor?' and Other Essays on European Integration. Cambridge: Cambridge University Press.

Wiener, Antje. 1997. "Making Sense of the New Geography of Citizenship: Fragmented Citizenship in the European Union." Theory and Society 26 (4): 529-60.

http://www.springerlink.com/index/T12129T5748687X7.pdf.

1998. European Citizenship Practice: Building Institutions of a Non-State. Boulder Co:

Westview Press. 
Tables

Table 1. Equality relations and principles of citizenship in multilateral democracy

\begin{tabular}{|c|c|c|c|}
\hline Realm & $\begin{array}{l}\text { Equality } \\
\text { Relations }\end{array}$ & Existing Principles & Implication for Citizenship \\
\hline \multirow[t]{6}{*}{ Supranational } & $\begin{array}{l}\text { 1. Equality of } \\
\text { Individuals }\end{array}$ & $\begin{array}{l}\text { Supremacy of multilateral } \\
\text { law and jurisdiction (P5) }\end{array}$ & $\begin{array}{l}\text { Equal implementation of supranational } \\
\text { rights in the whole system }\end{array}$ \\
\hline & & $\begin{array}{l}\text { Non-discrimination of } \\
\text { citizens (P2) }\end{array}$ & $>$ Residence-independent application \\
\hline & $\begin{array}{l}\text { 2. Equality of } \\
\text { Peoples }\end{array}$ & $\begin{array}{l}\text { Supremacy of multilateral } \\
\text { law and jurisdiction (P5) }\end{array}$ & $\begin{array}{l}\text { Legal security for the application of common } \\
\text { rules }\end{array}$ \\
\hline & & $\begin{array}{l}\text { Sovereignty of the } \\
\text { statespeoples' pouvoir } \\
\text { constituant (P1) }\end{array}$ & $\begin{array}{l}\text { Veto in the adoption of common rules for } \\
\text { access and loss of supranational citizenship }\end{array}$ \\
\hline & 3. Balancing & $\begin{array}{l}\text { Equal legislative rights of } \\
\text { citizens and statespeoples }\end{array}$ & $\begin{array}{l}\text { Participation rights for individuals to } \\
\text { establish legislative representation }\end{array}$ \\
\hline & & (P4) & $\begin{array}{l}\text { Veto of peoples in the adoption of common } \\
\text { rules for the supranational level }\end{array}$ \\
\hline \multirow[t]{6}{*}{ Transnational } & $\begin{array}{l}\text { 1. Equality of } \\
\text { Individuals }\end{array}$ & $\begin{array}{l}\text { Non-discrimination of } \\
\text { citizens (P2) }\end{array}$ & $\begin{array}{l}\text { Entry rights and political rights (gradually re- } \\
\text { establish full membership) }\end{array}$ \\
\hline & & & $\begin{array}{l}>\text { Non-discrimination for rights settled in } \\
\quad \text { Treaties }\end{array}$ \\
\hline & $\begin{array}{l}\text { 2. Equality of } \\
\text { Peoples }\end{array}$ & $\begin{array}{l}\text { Sovereignty of the } \\
\text { statespeoples' pouvoir }\end{array}$ & $\begin{array}{l}\text { Competence to regulate acquisition and loss } \\
\text { of national citizenship }\end{array}$ \\
\hline & & constituant (P1) & $>$ Veto in the adoption of common rules \\
\hline & & $\begin{array}{l}\text { Non-discrimination of } \\
\text { statespeoples(P2) }\end{array}$ & $\begin{array}{l}\text { Non-discrimination for rights settled in } \\
\text { Treaties }\end{array}$ \\
\hline & 3. Balancing & $\begin{array}{l}\text { Reciprocity of } \\
\text { transnational rights (P3) }\end{array}$ & $>$ Differentiated integration possible \\
\hline \multirow[t]{4}{*}{$\begin{array}{l}\text { Within } \\
\text { member } \\
\text { states }\end{array}$} & $\begin{array}{l}\text { 1. Equality of } \\
\text { Individuals }\end{array}$ & $\begin{array}{l}\text { Democratic rights as the } \\
\text { member states have to be } \\
\text { democratic (democratic }\end{array}$ & $>$ Minimum standards of political rights \\
\hline & & membership structure) & \\
\hline & $\begin{array}{l}\text { 2. Equality of } \\
\text { Peoples }\end{array}$ & $\begin{array}{l}\text { Sovereignty of the } \\
\text { statespeoples' pouvoir } \\
\text { constituant (P1) }\end{array}$ & $>$ Coexistence of different citizenship models \\
\hline & 3. Balancing & \multicolumn{2}{|c|}{$\begin{array}{l}\text { No tensions as the sovereignty of liberal democratic states is based on its } \\
\text { citizens }\end{array}$} \\
\hline
\end{tabular}


Table 2. Normative expectations for access and linkage of citizenship

\begin{tabular}{lllll}
\hline & \multicolumn{1}{c}{ Statist } & Unionist & \multicolumn{1}{c}{ Pluralist } & \multicolumn{1}{c}{$\begin{array}{c}\text { Multilateral } \\
\text { Democracy }\end{array}$} \\
\hline $\begin{array}{l}\text { Linkage of national and } \\
\text { supranational membership } \\
\text { Derivation }\end{array}$ & Strictly linked & $\begin{array}{l}\text { Strictly } \\
\text { linked } \\
\text { Top-down }\end{array}$ & $\begin{array}{l}\text { Disconnect for Third } \\
\text { Country Nationals } \\
\text { Bottom-up for } \\
\text { Nationals and EU } \\
\text { citizens }\end{array}$ & Disconnect \\
& Bottom-up & If linked, bottom-up \\
\hline Access to national level & $\begin{array}{l}\text { Self- } \\
\text { determination }\end{array}$ & Uniform & $\begin{array}{l}\text { Easier naturalisation } \\
\text { for EU citizens }\end{array}$ & Self-determination \\
\hline Access to supranational level & $\begin{array}{l}\text { Self- } \\
\text { determination }\end{array}$ & Uniform & $\begin{array}{l}\text { Easier naturalisation } \\
\text { for EU citizens }\end{array}$ & Uniform \\
\hline Access to transnational level & $\begin{array}{l}\text { Self- } \\
\text { determination }\end{array}$ & Uniform & $\begin{array}{l}\text { Easier naturalisation } \\
\text { for EU citizens }\end{array}$ & $\begin{array}{l}\text { Gradually re- } \\
\text { establishing full } \\
\text { membership }\end{array}$ \\
\hline Note: This Table draws on and extends the comparison of different models by Bauböck (2007). & \\
\hline
\end{tabular}


Table 3. Access and linkage models in comparison

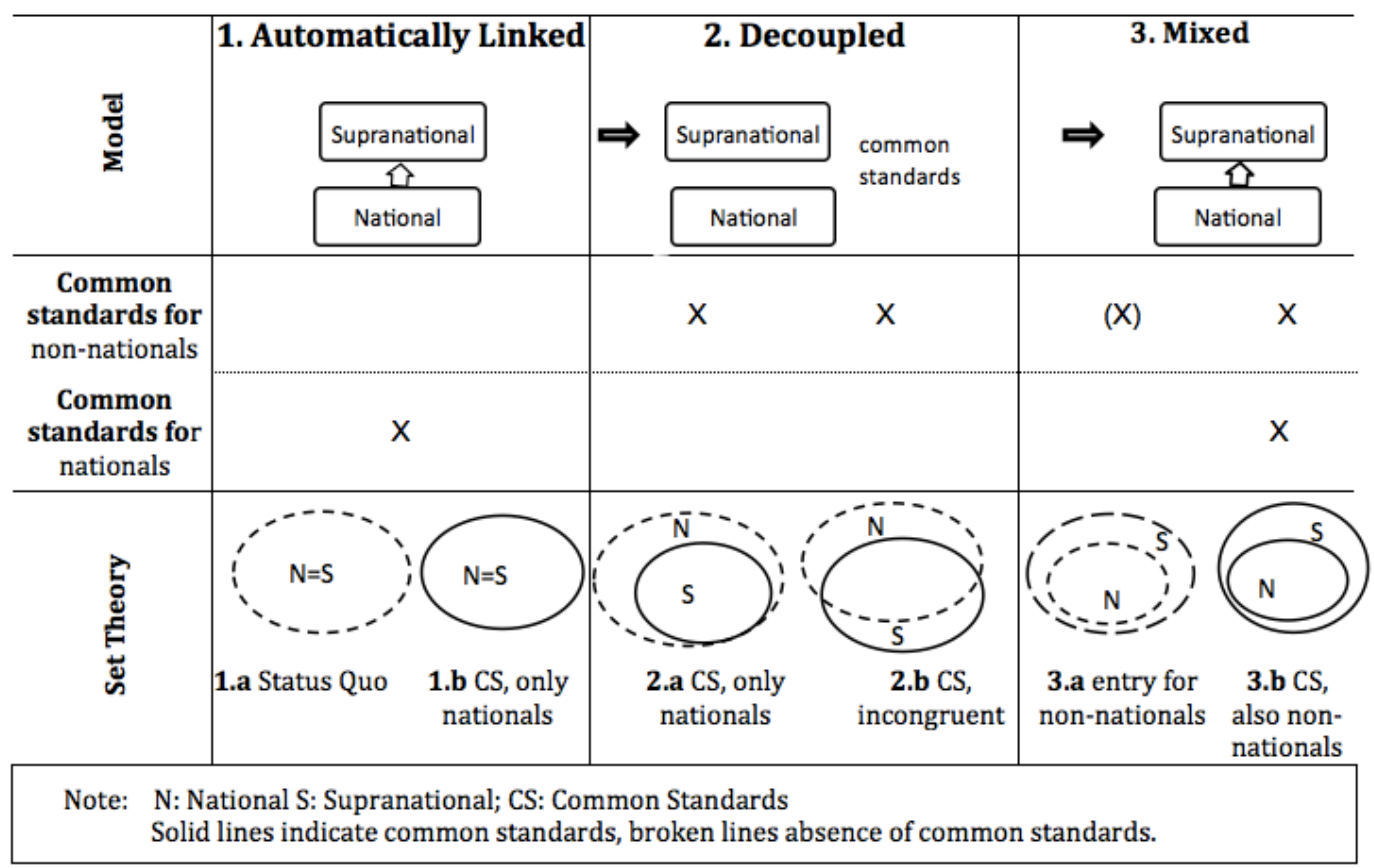

